\title{
Effects of established perennial grasses on yields of asso- ciated annual weeds
}

\author{
M.M. BORMAN, W.C. KRUEGER, AND D.E. JOHNSON
}

\begin{abstract}
Perennial grasses are needed for seeding annual grasslands in the Mediterranean/maritime climatic regime of southwest Oregon. Selection of plants for reseeding purposes would be facilitated by identification of perennial grasses that, once established, are able to suppress resident annual plant production. Perennial grasses were transplanted and allowed to establish in the absence of competition for the first growing season at 2 sites in the foothills of southwest Oregon. After the first growing season, resident annual plants were allowed to reinvade. Perennial grasses such as Berber orchardgrass (Dactylis glomerata L. var. Berber) and Idaho fescue (Festuca idahoensis Elmer) that begin growth early suppressed annuals more effectively than later growing perennial grasses such as intermediate and tall wheatgrasses (Agropyron intermedium (Host.) Beauv. and $A$. elongatum (Host.) Beauv., respectively). Of the perennial grasses adapted to these sites, those which initiated growth earliest, maintained some growth through winter months, and matured earliest were the best competitors.
\end{abstract}

Key Words: competition, reinvasion, native perennial grasses, introduced perennial grasses, resident annual plants, yellow starthistle, Mediterranean system, southwest Oregon

Past heavy grazing of foothills pastures and rangelands of southwestern Oregon have resulted in dominance by annual grasses such as medusahead ( Taeniatherum asperum Nevski), dogtail (Cynosurus echinatus L.), bulbous bluegrass (Poabulbosa L.), and ripgut brome (Bromus rigidus Roth.), and by assorted annual forbs including yellow starthistle (Centaurea solstitialis L.). Serious

Authors are range scientist, USDA-ARS, Ft. Keogh Livestock and Range Research Station, Miles City, Mont. 59301; professor and assistant professor, Dep. of Rangeland Resources, Oregon State University, Corvallis, Ore. 97331. At the time of the research, Borman was graduate research assistant, Dep. of Rangeland Resources, Oregon State University.

Authors wish to gratefully acknowledge Bob Ferns and Joe Dauenaueher for the contribution of their land to this research effort, Ron Mobley and his staff at the Jackson County Extension Office for their assistance and support, and John Yungen for advice and use of facilities at the Southern Oregon Experiment Station in Medford.

Submitted as Technical Paper 9133, Oregon Agricultural Experiment Station. Funding was provided by the Office of International Research and Development,

Oregon State University and Oregon Agricultural Experiment Station.

Manuscript accepted 14 September 1990. attempts are being made to restore valuable perennial forage species on these areas by reducing grazing pressure or by seeding. However, these alternatives are expensive.

In a Mediterranean/maritime climate, the potential value of perennial cool-season grasses lies in their ability to extend seasonal green forage beyond that supplied by resident annuals (mostly alien annual grasses and forbs) (Adams and Kay 1985). By extending growth into summer, perennial grasses should deplete a greater amount of soil moisture and provide additional shade, which may help suppress yellow starthistle.

Under conditions to which they are adapted, established mature perennial grasses have a natural competitive advantage over annual grasses (Harris 1967, Harris and Wilson 1970) because prior root development allows them to maintain contact with available soil moisture (Harris 1977). This argument tends to support the "inhibition" model of secondary succession proposed by Connell and Slatyer (1977), which states that once in place, species tend to resist invasion by competitors. The first occupants preempt space and continue to exclude or inhibit late colonists until the former die or are damaged.

Past efforts to reestablish perennial grasses in this area have failed most likely due to high levels of competition from annual weeds. Before expending additional resources attempting to establish perennial grass stands, evaluation of selected perennial grasses for their production potentials and their abilities to maintain a stand would be of value. Further research to determine effective establishment techniques would be warranted for those species able to maintain niche occupancy once established. Field studies that bypass the seedling establishment phase to determine species' potentials to maintain niche occupancy have not been tried under conditions similar to those in the study area. A primary objective of this study, conducted in the foothills of southwestern Oregon, was to evaluate the abilities of several selected perennial grasses to suppress production by resident annual plants once the perennials are established. 


\section{Materials and Methods}

\section{Study Site}

Two study sites were located in the foothills in Jackson Countyin southwest Oregon. Site 1 is located $3 \mathrm{~km}$ east of Phoenix. Site 1 characteristics include: Darrow silty clay loam (fine, montmorillonitic, mesic Vertic Argixerolls) soil; west aspect; $20-30 \%$ slope; and $500 \mathrm{~m}$ elevation. Site 2 is located about $5 \mathrm{~km}$ northeast of Ashland. Site 2 characteristics include: Carney clay (fine, montmorillonitic, mesic Typic Chromoxerets) soil; southwest aspect; 5-20\% slope; and $600 \mathrm{~m}$ elevation. The area is characterized by a Mediterranean/Maritime climate pattern with cool, wet winters and hot, dry summers. Annual precipitation averages $500 \mathrm{~mm}$ at both sites, but distribution and quantity vary considerably from year to year. On average, approximately $82 \%$ of the precipitation falls between 1 October and 30 April, $4.8 \%$ in May, $2.3 \%$ in June, and $0.7 \%$ in July. From December 1987 through June 1988, precipitation was 288 mm at both sites. From November 1988 through May 1989, Sites 1 and 2 received 438 and $429 \mathrm{~mm}$ precipitation, respectively. Distribution of precipitation was essentially the same at the 2 sites. The average January temperature is $3.3^{\circ} \mathrm{C}$ and the average July temperature is $21.1^{\circ} \mathrm{C}$. Extreme temperatures range from $-20^{\circ} \mathrm{C}$ to $41^{\circ} \mathrm{C}$. Temperature was continuously recorded with a hygrothermograph at each site. Daily temperature fluctuations were very similar for the 2 sites.

\section{Plant Materials}

Eleven species or varieties of species of perennial grass were evaluated. California oatgrass (Danthonia californica Bol.), Idaho fescue (Festuca idahoensis Elmer), and Junegrass (Koeleria cristata (L.) Pers.) were natives of the area growing in association with Oregon white oak (Quercus garryana Dougl.) on sites similar to the study sites. Tall wheatgrass (Agropyron elongatum (Host.) Beauv. var. Alkar), intermediate wheatgrass $(A$. intermedium (Host.) Beauv. var. Oahe), tall fescue (Festuca arundinacea Schreb. var. Alta), and perennial ryegrass (Lolium perenne $L$. var. Grimalda) were introduced species selected on the basis of results from screening trials conducted by the Soil Conservation Service (SCS) and the Jackson County Extension Office over a period of years in the study area (Hickman, SCS, Bend, Oregon, 1986, unpublished data). Berber and Palestine orchardgrass (Dactylis glomerata L. var. Berber and Palestine) were evaluated based on tests in California. Palestine orchardgrass originated in Israel and is considered drought resistant and adapted to the Mediterraneantype climate (Love 1969). Berber orchardgrass was initially tested in Australia, then in California and is considered superior to Palestine in survival and forage production (Adams and Kay 1985). Paiute orchardgrass ( $D$. glomerata L. var. Paiute) had recently been released from planting semiarid rangelands in the intermountain west (Monsen and Stevens 1985). Rush wheatgrass ( $A$. intermedium (Host.) Beauv. var. Rush) is in the process of being evaluated by the SCS at Corvallis, Ore.

\section{Plot Design}

Plot preparation included light rototilling followed by smoothing with a hand rake. Black vispore, 62 holes $\mathrm{cm}^{-2}$ that allowed water and air passage, was used to cover plots to suppress competition. There was no discernible effect on soil temperature at 2 or 20 $\mathrm{cm}$ depths as determined by permanently placed thermocouples constructed of copper-constantan wire. All perennial grasses were transplanted into plots and allowed to establish in the absence of competition during the 1986-87 growing season. Holes of $5 \mathrm{~cm}$ diameter were cut into the vispore where plants were to be transplanted. Vispore allowed no annual plant survival between perennial grass plants. California oatgrass, Idaho fescue and junegrass were transplanted as $5-\mathrm{cm}$ crown diameter sections of mature plants in November 1986. The introduced species were trans- planted in early March 1987 as seedlings which had been started in the greenhouse. Each species was randomly assigned to a plot. Plots consisted of 5 rows of 14 plants each with $25 \times 25-\mathrm{cm}$ spacing between and within rows. Following the first growing season, the plots were split into subplots by randomly removing the vispore from one-half of each plot. Resident annuals were thus allowed to reinvade and provide competition for the perennials on one subplot while the perennials remained competition free on the other subplot.

\section{Sampling}

The weight estimate technique (Pechanec and Pickford 1937) was used to sample vegetation within plots. Fifteen individual subsamples per subplot were obtained to determine a mean for each subplot. Plants on the perimeter of the plots and additional plants transplanted around the perimeter of each site served as calibration plants for estimation of perennial grass biomass. Resident annuals around the plot area served as calibration plants for annual grasses and forbs. Biomass and percent foliar cover of the annual grasses and annual forbs were estimated around each perennial grass plant in the uncovered subplots. Since perennial grass plants were transplanted in a $25-\mathrm{cm}$ grid, sampling for resident annuals around each plant was within a $25 \times 25-\mathrm{cm}$ square frame with the perennial grass plant in the center.

To assess the abilities of the perennial grasses to suppress resident annual reinvasion, sampling for the 1987-88 growing season was conducted in May and June at the peak of the growing season. During 1988-89 sampling was conducted at least once a month from mid-December through mid-June.

\section{Experimental Design and Analysis}

The study was conducted at 2 sites within the Rogue River Valley. The plot layout within each site consisted of 3 blocks each of which contained randomly assigned perennial grass species and control subplots. The control consisted of resident annual plants. A split-plot ANOVA was utilized. Each site was analyzed as a whole plot, and each perennial grass species and control as a subplot within site. Since Block 1 at Site 1 was not necessarily the same as Block 1 at Site 2, block was nested within site (i.e., Block (Site)) for the analysis rather than treated separately. Block (Site) served as the error term for Site. Species * Block (Site) served as the error team for Species and for Site * Species interactions. Aboveground biomass and percent cover of annual plants around each perennial grass plant $(25 \times 25-\mathrm{cm}$ area) were evaluated.

When several measurements are taken on the same experimental unit, the measurements tend to be correlated with each other. When measurements represent qualitatively different things such as weight, the correlation is taken into account by the use of multivariate methods such as multivariate analysis of variance (MANOVA) (SAS 1987, p 602). To account for auto-correlation of dates of sampling, MANOVA was first conducted to provide a conservative screen for significant differences. Subsequently, univariate analyses were conducted for each sampling date when differences were detected in the initial multivariate analysis. Discussion is based on results of univariate analyses. Mean separation via a F-protected LSD (Petersen 1985) followed a significant Fratio of at least $P \leq 0.10$.

Linear contrasts were used for the spring and summer 1989 sampling periods to determine differences in annual plant production and cover among and within perennial grass groups. Contrasts included Idaho fescue vs orchardgrasses, Idaho fescue vs wheatgrasses, orchardgrasses vs wheatgrasses, Berber vs Palestine orchardgrass, and tall vs intermediate wheatgrass.

\section{Results and Discussion}

California oatgrass did not survive transplanting, and plots 
Table 1. May 1988 mean percent foliar cover (percent cover) and dry matter biomass of resident annual plants in a $25 \times 25 \mathrm{~cm}$ area surrounding individual perennial grass plants.

\begin{tabular}{|c|c|c|}
\hline Species & $\begin{array}{c}\text { Percent } \\
\text { Cover }\end{array}$ & $\begin{array}{c}\text { Dry } \\
\text { Matter }(\mathrm{g})^{\prime}\end{array}$ \\
\hline $\begin{array}{l}\text { (Site 1) } \\
\text { Tall wheatgrass } \\
\text { Intermediate wheatgrass } \\
\text { Rush wheatgrass } \\
\text { Berber orchardgrass } \\
\text { Palestine orchardgrass } \\
\text { Paiute orchardgrass } \\
\text { Perennial ryegrass } \\
\text { Tall fescue } \\
\text { Idaho fescue } \\
\text { Junegrass } \\
\text { California oatgrass } \\
\text { resident annuals only }\end{array}$ & $\begin{array}{rl}12.9 & \mathrm{de}^{2} \\
17.5 & \mathrm{de}^{2} \\
24.5 & \mathrm{de} \\
9.1 & \mathrm{e} \\
12.6 \mathrm{de} & \\
42.2 \mathrm{c}^{2} & \\
60.8 \mathrm{~b} \\
26.0 \mathrm{~d} \\
25.6 \mathrm{~d} \\
56.0 \mathrm{bc} \\
63.8 \mathrm{~b} \\
93.6 \mathrm{a}\end{array}$ & 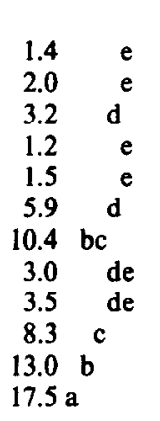 \\
\hline Site 1 average & $37.0 \mathrm{~A}^{3}$ & $5.9 \mathrm{~A}$ \\
\hline $\begin{array}{l}\text { (Site 2) } \\
\text { Tall wheatgrass } \\
\text { Intermediate wheatgrass } \\
\text { Rush wheatgrass } \\
\text { Berber orchardgrass } \\
\text { Palestine orchardgrass } \\
\text { Paiute orchardgrass } \\
\text { Perennial ryegrass } \\
\text { Tall fescue } \\
\text { Idaho fescue } \\
\text { Junegrass } \\
\text { California oatgrass } \\
\text { resident annuals only }\end{array}$ & $\begin{array}{rl}10.8 & \mathrm{e} \\
12.8 \mathrm{de} \\
23.7 \text { c } \\
8.3 \text { e } \\
8.2 \text { e } \\
35.4 \text { bc } \\
35.9 \text { bc } \\
26.7 \text { bcd } \\
2.2 \text { e } \\
42.4 \text { b } \\
90.8 \text { a } \\
82.3 \mathrm{a}\end{array}$ & \begin{tabular}{ll}
1.4 & \multicolumn{1}{c}{ fg } \\
4.0 & ef \\
4.3 & ef \\
1.2 & \\
1.0 & g \\
7.1 & cde \\
8.0 & cd \\
4.9 & def \\
0.3 & g \\
$9.0 \quad$ c \\
$23.0 \mathrm{a}$ \\
17.9 b
\end{tabular} \\
\hline Site 2 average & $32.6 \mathrm{~A}$ & $6.9 \mathrm{~A}$ \\
\hline
\end{tabular}

'grams dry matter * $160=\mathrm{kg} / \mathrm{ha}$

2 Within column and site, species means with the same lower case letter are not significantly different at $P<0.10$.

${ }^{3}$ Within column, site averages with the same upper case letter are not significantly different at $P<0.10$.

became dominated by dogtail. Other perennial grasses were able to suppress resident annuals to some extent; however, major differences were detected in May and June 1988. Junegrass and perennial ryegrass were consistently least able to suppress annuals (Tables 1 and 2). Of the wheatgrasses, Rush wheatgrass was least effective at suppressing annuals. Of the 3 orchardgrasses, Paiute was by far least effective. At the other extreme, results varied somewhat between the 2 sites. At Site 1 , although not statistically significantly different from several other perennial grasses, cover and biomass of annuals seemed less in Berber orchardgrass plots in both May and June. Annual plant biomass and cover were similar in plots of Palestine orchardgrass, the 3 wheatgrasses, Idaho fescue, and tall fescue. At Site 2, Idaho fescue was consistently effective in suppressing resident annual plant production. Berber and Palestine orchardgrasses and tall wheatgrass were consistently nearly as effective.

Differences in perennial grass peak standing crop biomass between subplots subject to competition and those protected from competition served as an additional index of the competitive abilities of the perennial grasses (Table 3). Rush wheatgrass, Paiute orchardgrass, perennial ryegrass, and tall fescue all suffered from competition by resident annual plants at both sites.

On the basis of their inabilities to compete effectively with resident annual species during the first year, Rush wheatgrass, Paiute orchardgrass, perennial ryegrass, tall fescue, junegrass, and California oatgrass were not sampled on a periodic basis during the second year, 1988-89. Idaho fescue, Berber and Palestine orchardgrass, tall and intermediate wheatgrass were considered to have enough potential to merit continued sampling.
Table 2. June 1988 mean percent foliar cover (percent cover) and dry matter biomass of resident annual plants in $a 25 \times 25 \mathrm{~cm}$ area surrounding individual perennial grass plants.

\begin{tabular}{lcc}
\hline \hline Species & $\begin{array}{c}\text { Percent } \\
\text { Cover }\end{array}$ & $\begin{array}{c}\text { Dry } \\
\text { Matter }(g)^{1}\end{array}$ \\
\hline (Site 1) & & \\
Tall wheatgrass & $4.1 \mathrm{~d}^{2}$ & $0.7 \mathrm{~d}$ \\
Intermediate wheatgrass & $9.6 \mathrm{~cd}$ & $1.4 \mathrm{~cd}$ \\
Rush wheatgrass & $13.7 \mathrm{~cd}$ & $3.2 \mathrm{~cd}$ \\
Berber orchardgrass & $3.9 \mathrm{~d}$ & $0.6 \mathrm{~d}$ \\
Palestine orchardgrass & $5.7 \mathrm{~cd}$ & $1.0 \mathrm{~d}$ \\
Paiute orchardgrass & $20.3 \mathrm{c}$ & $3.5 \mathrm{~cd}$ \\
Perennial ryegrass & $50.6 \mathrm{~b}$ & $16.1 \mathrm{ab}$ \\
Tall fescue & $9.6 \mathrm{~cd}$ & $1.4 \mathrm{~cd}$ \\
Idaho fescue & $14.4 \mathrm{c}$ & $3.3 \mathrm{~cd}$ \\
Junegrass & $46.6 \mathrm{~b}$ & $8.8 \mathrm{bc}$ \\
California oatgrass & $80.6 \mathrm{a}$ & $21.7 \mathrm{a}$ \\
resident annuals only & $78.9 \mathrm{a}$ & $15.2 \mathrm{ab}$ \\
Site 1 average & $28.0 \mathrm{~A}^{3}$ & $6.4 \mathrm{~A}$
\end{tabular}

(Site 2)

Tall wheatgrass

Intermediate wheatgrass

Rush wheatgrass

Berber orchardgrass

Palestine orchardgrass

Paiute orchardgrass

Perennial ryegrass

Tall fescue

Idaho fescue

Junegrass

California oatgrass

resident annuals only

$6.1 \mathrm{cef}$
$25.3 \mathrm{~cd}$
$16.4 \mathrm{de}$
$3.1 \mathrm{cf}$
$4.8 \mathrm{cf}$
$21.6 \mathrm{~cd}$
$31.1 \mathrm{bc}$
$22.0 \mathrm{~cd}$
1.5
$45.0 \mathrm{~b}$
$81.8 \mathrm{a}$
$42.7 \mathrm{~b}$
$25.1 \mathrm{~B}$

$1.5 \mathrm{de}$

$10.1 \mathrm{c}$

$6.2 \mathrm{c}$

0.7 e

$1.3 \mathrm{de}$

$8.8 \mathrm{~cd}$

19.4 a

7.2 cde

0.3 e

$18.2 \mathrm{ab}$

$22.8 \mathrm{a}$

$10.7 \mathrm{bc}$

Site 2 average

Igrams dry matter * $160=\mathrm{kg} / \mathrm{ha}$

2 Within column and site, species means with the same lower case letter are not significantly different at $P<0.10$.

${ }^{3}$ Within column, site averages with the same upper case letter are not significantly different at $P<0.10$.

Results from December 1988 and January 1989 indicated perennial grasses were similar in suppressing resident annuals early in the growing season (data not shown). In December there were no site differences. January results indicated a site by species interaction (Borman 1989). The interaction resulted from site differences in resident annual biomass production in the control plots. Production was greater at Site $1(4.1 \mathrm{I} \mathrm{g}$ /quadrat vs $2.69 \mathrm{~g} /$ quadrat at Sites 1 and 2, respectively, $P<0.10$ ). Growth began earlier at Site 1

Table 3. 1988 above ground peak standing crop biomass (g/plant) of perennial grass plants with and without competition from resident annual plants.

\begin{tabular}{|c|c|c|c|c|c|c|}
\hline \multirow[b]{2}{*}{ Species } & \multicolumn{3}{|c|}{ Site 1} & \multicolumn{3}{|c|}{ Site 2} \\
\hline & $\begin{array}{l}\text { compe- } \\
\text { tition }\end{array}$ & $\begin{array}{c}\text { no } \\
\text { compe- } \\
\text { tition }\end{array}$ & $P$ & $\begin{array}{c}\text { compe- } \\
\text { tition }\end{array}$ & $\begin{array}{c}\text { no } \\
\text { compe- } \\
\text { tition }\end{array}$ & $P$ \\
\hline Tall wheatgrass & 23.4 & 19.7 & 0.355 & 16.2 & 21.3 & 0.038 \\
\hline $\begin{array}{l}\text { Intermediate } \\
\text { wheatgrass }\end{array}$ & 23.5 & 26.0 & 0.507 & 32.8 & 38.7 & 0.319 \\
\hline Rush wheatgrass & 17.5 & 26.7 & 0.0001 & 20.0 & 43.6 & 0.0001 \\
\hline Berber orchardgrass & 18.2 & 20.5 & 0.223 & 28.1 & 36.7 & 0.004 \\
\hline $\begin{array}{l}\text { Palestine } \\
\text { orchardgrass }\end{array}$ & 16.4 & 26.2 & 0.0001 & 27.3 & 30.3 & 0.380 \\
\hline Paiute orchardgrass & 10.5 & 17.9 & 0.0006 & 17.9 & 33.7 & 0.0001 \\
\hline Perennial ryegrass & 6.4 & 13.4 & 0.0001 & 14.8 & 28.2 & 0.005 \\
\hline Tall fescue & 10.9 & 18.8 & 0.0001 & 9.5 & 18.3 & 0.0002 \\
\hline Idaho fescue & 20.9 & 23.1 & 0.196 & 39.7 & 43.2 & 0.497 \\
\hline Junegrass & 12.6 & 16.9 & 0.025 & 12.7 & 16.0 & 0.279 \\
\hline
\end{tabular}


for both resident annuals and perennial grasses (Borman 1989, Borman et al. 1990). Site differences persisted when control plots (resident annuals only) were eliminated from the analyses $(0.93 \mathrm{~g} \mathrm{vs}$ $0.70 \mathrm{~g}$ /quadrat at Sites 1 and 2 , respectively, $\mathrm{P}<0.10$ ); however, resident annual production was similar among the perennial grass plots within each site.

Table 4. Early Spring 1989 species main effects mean percent foliar cover (percent cover) and dry matter biomass of resident annuals plants in a 25 $\times 25 \mathrm{~cm}$ area surrounding individual perennial grass plants.

\begin{tabular}{|c|c|c|c|c|}
\hline \multirow{3}{*}{$\frac{\text { Species }}{\text { Idaho fescue }}$} & \multicolumn{2}{|c|}{16 March } & \multicolumn{2}{|c|}{5 April } \\
\hline & $\begin{array}{l}\text { Percent } \\
\text { cover }\end{array}$ & $\begin{array}{c}\text { Dry } \\
\text { matter }(\mathrm{g})^{1}\end{array}$ & $\begin{array}{l}\text { Percent } \\
\text { cover }\end{array}$ & $\begin{array}{c}\text { Dry } \\
\text { matter }(g)^{1}\end{array}$ \\
\hline & $46.8 \mathrm{bcd}^{2}$ & $1.7 \mathrm{bcd}$ & $59.6 b^{2}$ & $1.8 \mathrm{bc}$ \\
\hline $\begin{array}{l}\text { Berber } \\
\quad \text { orchardgrass }\end{array}$ & $38.9 \quad \mathrm{~d}$ & $1.0 \mathrm{~d}$ & 44.2 & $1.0 \mathrm{c}$ \\
\hline $\begin{array}{l}\text { Palestine } \\
\text { orchardgrass }\end{array}$ & $44.7 \mathrm{~cd}$ & $1.5 \mathrm{~cd}$ & $52.2 \mathrm{~cd}$ & $1.9 \mathrm{~b}$ \\
\hline Tall wheatgrass & $59.3 \mathrm{bc}$ & $2.1 \mathrm{bc}$ & $65.2 \mathrm{bc}$ & $2.3 \mathrm{~b}$ \\
\hline $\begin{array}{l}\text { Intermediate } \\
\text { wheatgrass }\end{array}$ & $60.6 \mathrm{~b}$ & $2.5 \mathrm{~b}$ & $69.5 \mathrm{~b}$ & $2.6 \mathrm{~b}$ \\
\hline $\begin{array}{l}\text { resident annuals } \\
\text { only }\end{array}$ & $82.2 \mathrm{a}$ & $4.9 \mathrm{a}$ & $88.8 \mathrm{a}$ & $5.2 \mathrm{a}$ \\
\hline
\end{tabular}

Igrams dry matter * $160=\mathrm{kg} / \mathrm{ha}$

${ }_{2 W}$ Within column, species means with the same letter are not significantly different at $P<0.10$.

Species differences were beginning to appear in March (Table 4). Orchardgrass plots had less resident annual cover and biomass than the wheatgrass plots. A similar response occurred at both sites. Site differences persisted as a result of differential fall and winter growth. Orchardgrass plants initiated growth in the fall and maintained some growth through the winter while the wheatgrasses did not initiate growth until spring (Borman 1989, Borman et al. 1990). A greater annual plant biomass was produced at Site 1 compared to Site 2 (2.92 and $1.62 \mathrm{~g} /$ quadrat Sites 1 and 2, respectively, $P<0.10)$ through winter.

By 5 April, growth rates at Site 2 had accelerated, and site differences in resident annual cover and biomass disappeared. Species differences persisted with slight changes (Table 4). Berber orchardgrass was still most effective in suppressing annual plant growth. Annual plant yields were similar among the other species $(P>0.10)$.
Resident annual biomass at Site 2 was greater than at Site 1 by 15 April (Table 5). Differences at Site 1 were still somewhat obscure among individual species, however; on the basis of linear contrasts orchardgrasses were more effective than both Idaho fescue (P = 0.01 , both cover and biomass) and wheatgrasses $(P=0.01$, cover and $P=0.03$, biomass). Differences at Site 2 were more definite, with Berber orchardgrass and Idaho fescue clearly more effective than wheatgrasses at suppressing annuals (Table 5). Between orchardgrasses, Berber suppressed annual plants more effectively than Palestine ( $\mathrm{P}=0.17$, cover and $\mathrm{P}=0.08$ biomass).

Site differences persisted in mid-May (Table 5). At Site 1, orchardgrasses appeared most effective and intermediate wheatgrass least effective in suppressing resident annual plant growth. Based on linear contrasts, orchardgrasses were more effective than both Idaho fescue $(P=0.03$, cover and $P=0.07$, biomass $)$ and wheatgrasses $(P=0.005$, cover and $P=0.03$, biomass). At Site 2 , Berber orchardgrass and Idaho fescue were most effective suppressing annuals (Table 5). Linear contrasts showed orchardgrasses were more effective than wheatgrasses $(P=0.001$, cover and $P=0.01$, biomass). Berber was more effective than Palestine orchardgrass $(P=0.07$, cover and $P=0.18$, biomass).

Site differences were extreme by mid-June (Table 5). Yellow starthistle, the only annual plant of consequence by this time, was far more robust at Site 2 than Site 1 and accounted for the difference. With relatively little competitive interference, suppression of annual plant growth was similar among the perennial grasses at Site $1(P>0.10)$. At Site 2, Berber orchardgrass and Idaho fescue were still most effective at suppressing yellow starthistle. Based on linear contrasts, orchardgrasses were more effective at suppressing yellow starthistle than were wheatgrasses $(P=0.02$, cover and $P=$ 0.04 , biomass). Idaho fescue was more effective than wheatgrasses ( $P=0.01$, cover and $P=0.05$, biomass). Within the orchardgrasses, Berber was more effective than Palestine at suppressing yellow starthistle $(P=0.04$, cover and $P=0.05$, biomass $)$.

\section{Conclusions}

Although variability in the data was frequently enough to obscure the differences among perennial grasses in terms of their respective abilities to suppress annual plant growth, relative differences can be discerned after 2 years of study. After the first year of

Table 5. Spring and summer 1989 , site and species mean percent foliar cover (percent cover) and dry matter biomass of resident annual plants in a $25 \times 25$ cm area surrounding individual perennial grass plants.

\begin{tabular}{|c|c|c|c|c|c|c|}
\hline \multirow[b]{2}{*}{ Species } & \multicolumn{2}{|c|}{15 April } & \multicolumn{2}{|c|}{$20 \mathrm{May}$} & \multicolumn{2}{|c|}{15 June } \\
\hline & Percent cover & Dry matter $(\mathrm{g})^{1}$ & Percent cover & Dry matter (g) & Percent cover & Dry matter (g) \\
\hline \multicolumn{7}{|l|}{ (Site 1) } \\
\hline Idaho fescue & $72.0 \mathrm{ab}^{2}$ & $3.6 \mathrm{~b}$ & $59.9 \mathrm{bc}$ & $9.0 \mathrm{bc}$ & 18.4 & $4.1 \mathrm{~b}$ \\
\hline Berber orchardgrass & $37.9 \quad \mathrm{~d}$ & $1.3 \mathrm{c}$ & $41.1 \mathrm{~cd}$ & $3.1 \mathrm{~d}$ & 11.8 & $2.2 \mathrm{~b}$ \\
\hline Palestine orchardgrass & $43.6 \mathrm{~cd}$ & $1.8 \mathrm{bc}$ & $27.7 \quad \mathrm{~d}$ & $4.4 \mathrm{~cd}$ & $15.3 \mathrm{c}$ & $2.7 \mathrm{~b}$ \\
\hline Tall wheatgrass & $61.5 \mathrm{bc}$ & $2.6 \mathrm{bc}$ & $59.0 \mathrm{bc}$ & 7.7 bcd & $16.6 \mathrm{c}$ & $3.6 \mathrm{~b}$ \\
\hline Intermediate wheatgrass & $73.2 \mathrm{ab}$ & $3.4 \mathrm{~b}$ & $70.5 \mathrm{~b}$ & $10.5 \mathrm{~b}$ & $38.5 \mathrm{~b}$ & $5.7 \mathrm{~b}$ \\
\hline Resident annuals only & $91.3 \mathrm{a}$ & $6.2 \mathrm{a}$ & $95.0 \mathrm{a}$ & $18.5 \mathrm{a}$ & $88.3 \mathrm{a}$ & $14.2 \mathrm{a}$ \\
\hline Site 1 average & $63.3 \mathrm{~A}^{3}$ & $3.2 \mathrm{~B}$ & $58.9 \mathrm{~B}$ & $8.9 \mathrm{~B}$ & $31.5 \mathrm{~B}$ & $5.4 \mathrm{~B}$ \\
\hline \multicolumn{7}{|l|}{ (Site 2) } \\
\hline Idaho fescue & $50.9 \mathrm{bc}$ & $2.5 \mathrm{c}$ & 51.1 & 7.2 & 36.0 & $19.9 \mathrm{~cd}$ \\
\hline Berber orchardgrass & $45.2 \mathrm{c}$ & $2.3 \mathrm{c}$ & $53.4 d$ & 6.3 & $32.0 \mathrm{c}$ & $14.1 \quad \mathrm{~d}$ \\
\hline Palestine orchardgrass & $62.7 \mathrm{bc}$ & $4.8 \mathrm{~b}$ & $69.6 \mathrm{c}$ & $10.0 \mathrm{bc}$ & $56.3 \mathrm{~b}$ & $28.9 \mathrm{bc}$ \\
\hline Tall wheatgrass & $65.4 \mathrm{~b}$ & $5.3 \mathrm{~b}$ & $96.8 \mathrm{ab}$ & $14.7 \mathrm{~b}$ & $57.9 \mathrm{~b}$ & $31.5 \mathrm{bc}$ \\
\hline Intermediate wheatgrass & $64.5 \mathrm{~b}$ & $5.3 \mathrm{~b}$ & $83.1 \mathrm{bc}$ & $13.6 \mathrm{~b}$ & $71.5 \mathrm{~b}$ & $34.7 \mathrm{~b}$ \\
\hline Resident annuals only & $88.6 \mathrm{a}$ & $11.1 \mathrm{a}$ & $97.8 \mathrm{a}$ & $23.6 \mathrm{a}$ & $98.6 \mathrm{a}$ & $53.6 \mathrm{a}$ \\
\hline Site 2 average & $62.9 \mathrm{~A}$ & $5.2 \mathrm{~A}$ & $75.3 \mathrm{~A}$ & $12.6 \mathrm{~A}$ & $58.7 \mathrm{~A}$ & $30.4 \mathrm{~A}$ \\
\hline
\end{tabular}

'Grams dry matter $* 160=\mathrm{kg} / \mathrm{ha}$.

2Within column and site, species means with the same lower case letter are not significantly different at $P<0.10$

${ }^{3}$ Within column, site averages with the same upper case letter are not significantly different at $P<0.10$. 
study, Rush wheatgrass, Paiute orchardgrass, perennial ryegrass, tall fescue, junegrass, and California oatgrass were eliminated from further consideration on the basis of their inabilities to compete effectively with resident annual species. Effectiveness of the remaining species in suppressing resident annuals corresponded to their periods of active growth. Perennial grasses beginning growth earliest and continuing growth through winter, such as Berber orchardgrass and Idaho fescue (Borman 1989, Borman et al. 1990), suppressed annuals more effectively than did perennial grasses beginning growth later with little winter growth, such as intermediate and tall wheatgrasses (Borman 1989, Borman et al. 1990). From a management perspective, perennial grasses not capable of growing through the winter should not be selected for reseeding southern Oregon foothills. Suppression of annuals is most important for stand maintenance on the more productive sites in this region as represented by Site 2 in this study. Additional research is needed to determine effective establishment techniques for Idaho fescue and Berber and Palestine orchardgrass, which appear capable of maintaining a stand based on results from this study. Proper management, grazing and other, for stand maintenance also needs to be researched before species recommendations can be made with confidence.

\section{Literature Cited}

Adams, T.E., Jr., and B.L. Kay. 1985. Perennial grasses for California rangelands. Range Sciences Rep. 3, Dep. Agron. and Range Sci., Univ. of California, Davis.

Borman, M.M. 1989. Growth characteristics and site potentials of perennial grass species. PhD thesis, Oregon State Univ., Corvallis.

Borman, M.M., W.C. Krueger, and D.E. Johnson. 1990. Growth patterns of perennial grasses in the annual grassland type of Southwest Oregon. Agron. J., Nov.-Dec. 1990.

Connell, J.H., and R.O. Slatyer. 1977. Mechanisms of succession in natural communities and their role in community stability and organization. The American Natur. 111:1119-1144.

Harris, G.A. 1967. Some competitive relationships between Agropyron spicatum and Bromus tectorum. Ecological Monographs 37:89-111.

Harris, G. 1977. Root phenology as a factor of competition among grass seedlings. J. Range Manage. 30:172-177.

Harris, G.A., and A.M. Wilson. 1970. Competition for moisture among seedlings of annual and perennial grasses as influenced by root elongation at low temperature. Ecology 51:530-534.

Love, R.M. 1969. Registration of Palestine orchardgrass. Crop Sci. 9:53.

Monsen, S.B., and R. Stevens. 1985. 'Paiute' orchardgrass-forage species for semi-arid range and wildland sites. Rangelands 7:114-115.

Pechanec, J.F., and G.D. Pickford. 1937. A weight estimate method for the determination of range or pasture production. J. of Amer. Soc. Agron. 29:894-904.

Petersen, R.G. 1985. Design and analysis of experiments. Marcel Dekker, Inc., New York.

SAS Institute Inc. 1987. SAS/STAT ${ }^{\mathrm{IM}}$ Guide for personal computers, version 6 edition. Cary, N.C.

ERRATA:Provenza, F.D. 1991. Viewpoint: Range science and range management are complementary but distinct endeavors. J. Range Manage. 44:181-183.

in its section "Planning and Science" fails to quote passages amounting to about 250 words which appear in the following paper:

Romesburg, H.C. 1981. Wildlife science; gaining reliable knowledge. J. Wildl. Manage. 45:293-313.

Provenza's failure to quote was unintentional. Those who would quote passages from his article appearing in the section in question should, where the passages appear in Romesburg's article, instead quote and reference the latter. 